\title{
Student-Teachers Knowledge and Acquisition of Computer in Sandwich Programme of University of Abuja, Nigeria
}

\author{
J. N. Anene, J. C. Ikerionwu, E.N. Danladi \\ Department of arts and Social Science Education, University of Abuja Nigeria
}

\begin{abstract}
It is a fact that Nigerian youths cannot become computer literate unless their teachers are. This study was embarked upon to determine the extent of computer literacy among undergraduate studentteachers who already teachers in secondary schools in the Federal Capital Territory of Nigeria. The instrument used in the study was questionnaire. Statistical method employed in analysing data in the study was percentages, mean and T-test statistic. The findings of the study revealed that majority of the undergraduate student-teachers are not computer literate; also, computers are not available in schools where they teach. The under graduate studentteachers are willing to embark on computer training if sponsored. Furthermore, male and female undergraduate student-teachers perception did not differ as regards to their computer literacy. One of the recommendations was that government should partnership with banks to provide opportunities for teachers to acquire computer skills.
\end{abstract}

\section{Introduction}

Technology is important and essential for the survival of any nation. Education and advanced technology are important variables in the development of any society. It is clear that as we face the realities of the present and future, "technological age will engulf education," in the global world. Traditional education over the years has shifted towards these innovative methods of teaching and learning through the propagation of ICT. Today, technology enhanced learning, which includes distance and online instruction, is recognized as a viable tool necessary for preparing citizens to participate in the technologically driven global environment. In education the use of Information and Communication Technologies (ICT) has become more and more acceptable and popular all over the world. There has been a staggering amount of research and publication related to ICT use for educational purposes during the past decade in the more advanced industrialized nations. Nearly everyone of recent in the industrialized nations has gained access to ICT, the purchase of computers for school use in such nations as the United States has been increasing in such a pace that is difficult to keep track of how many computer machines are now in American schools.

According to Aduwa-Ogiegbaen and Iyamu [16] a survey carried out on the instructional uses of computers in United States public and private schools, suggests that over one million computers are in American elementary schools. The report also revealed that more than half-a-million teachers used computers for instructional purposes during 1985 and the same period and half of American secondary schools owed at least 15 computers each. This figures must have risen astronomically by now considering the fast pace of ICT in the last 20 years in Europe and America,. The story in Britain is basically the same as that of the USA according to Thomas. These countries have been able to keep such pace as a result of government funding through the local Education in the United State, Authorities and the Education Reforms Act of 1988 that compelled the central government to make budgetary provision for education technology.

There seem to be gradual developments in the Nigerian education sector as regards to the application of ICT in schools. The National Policy on education of Nigeria recognizes the prominent role of ICTs in the modern world and has integrated ICTs into education in Nigeria [1]. However, effort to move it further to become comparable with other developed countries has not really paid off. It has therefore become imperative that Nigeria leaders and educators should address this [5]. This is because, prospect of higher education in Nigeria in the near future relies on these educational technologies. Technology enhanced learning, including distance and online instruction, is recognised as a viable tool necessary for preparing citizens to participate in the technologically driven global environment in recent time. Thus, any society that wants its citizens to be 
competent with the use of modern technologies, has to properly educate the people who are entrusted with the responsibility of education of the youths in the society. It is obvious that our youths cannot become computer literate unless their teachers are computer literate themselves. According to one of the Millennium development goals of the Nigerian nation in education industry is that schools must be Information and Communication Technology (ICT) compliant Obike, and Afangideh [13].

Both students and teachers need communication in the distance learning, this is because it as have an important role to play and is a major relevant to tool to them,. Students need to know their roles in the use of various technologies to communicate with the teacher and with one another. Students not only to understand communication etiquette needed by the teacher in an online learning environment, but should also know how to use microphone or how to post information to bulletin board. While students must also understand what is expected of them in terms of the responses, the materials that are needed must be prepared in advance, Ezema [12].

A teacher is a person who provides education for pupils (children and students (adults). An effective is teacher expected to know how to uses variety of media in their lessons. In this $21 \mathrm{st}$ century generation, the students are born in the digital age and they are well exposed and aware of technological advances more than their unlike or any other generation before them. It has therefore become important that teachers must acquire this technology in order to be in tune with their students. This does not mean that we should eliminate textbooks and worksheets completely.

Effective teachers in urban and rural are not afraid to implement other forms of media within their lessons. While in most cases, urban teacher because they are placed in the urban setting and being nearer to government and the people concerned with educational matters, they hardly have problem of resources to teach unlike the teacher in rural areas. In general, the issue of resources, or lack of them, is frequently addressed as a concern of rural schools. Since rural schools often have limited resources, teachers must "make do" with what is available. For example, rural schools are often in need of textbooks, up-to-date computer programs and IT services, and support services. Also, economic decline in rural areas has affected the amount of money that can be raised through local property tax levies. Urban teachers have more opportunities to specialize in their subject area and enjoyed easier access to professional development opportunities.

\section{Background to the study}

The poor socio-economic condition in most developing countries of the world, including Nigeria, has compelled the governments and institutions to show little concern for the application of ICT in education. Though the Government is beginning to shows their commitment towards information technology by mandating the National Universities Commission to investment in ICT infrastructure, management information systems, e-mail access and library information services in Nigerian University Still, many institutions find it difficult to conceptualize and implement initiatives locally. Many institutions in Nigeria cannot afford or have access to computers and even where computers are available or can be purchased, there are lack of the human and material resources to use ICT Onyeachu. [15] Furthermore, computers that are bought for educational purposes are now stored in principals' offices unused in our schools nationwide, reasons ranges from lack of computer as well as experts' knowledge in the use of computer lack of manpower to operate them. Onyeachu opined that since ICTs require electricity for their use, where there is power failure, users will be stranded, and as such, computer education and ICT compliance cannot be achieved [11].

The availability, competence and the attitude of teachers towards the role of modern technologies in teaching and learning to cater for the ever increasing population of students in the schools will depend on the successful integration of ICT in the school (Chattel [17] and Cheng, [3]. Teachers' inability to apply ICT in teaching school subjects in our secondary schools is one of the problems militating against effective implementation of secondary education curriculum. Majority of secondary school teachers do not use computers while teaching their lessons. This can be attributed to many factors which include problem of electricity.

The integrating computer technology into teacher training programmes has been the system in many developed (and some developing) nations for some time now. Nigeria institutions currently lack any formal and serious plan for integrating computer technology into teacher training programmes. It is important to emphasis that if the objectives of the UBE and MLP are to be achieved, the training of teachers should involve integrating the use of modern instructional technologies, such as the computers, access to the Internet, audio-visual equipment, Video Conferencing, projectors, and traditional software used in today's business world - word processing, spreadsheets, databases, etc. Connecting our 
classrooms to the Internet is not enough. It is very understandable that proper "use of technology affects the way teachers teach, students learn, and administrators operate" Anon [2]. The objective is not to make the would-be-teachers to become technical experts, but to enable them acquire the basic computer skills and terminologies most often used by teachers, such as CPU, memory, desktop, keyboard, file, drive, save, and input and output devices. The acquired skills would enable teachers to use modern classroom technologies, and impart the knowledge to students. In other words, when teachers become familiarized with computing environment, they would be able to effectively teach our youths.

In many civilized and technologically advanced nations as such the United States, the use of computers and other instructional technologies have become common place in the classrooms. This is not to say that all teachers in those countries are computer wizards of some sort, some still do not know how to save a document on a floppy diskette. But there are alarming number of people in Nigeria (University professors and high school teachers included) who do not know how to simply turn on a computer. Yet, the society expects them to "perform wonders" some teachers of old (those who have been in the field long before the advent of the computers in the classroom) are intimidated by the computers. Some believe that is already too late for them to start learning computer basics, some would think that the computer would "break" if they "punched a wrong key" or pressed very hard on the keys Wang [18]. This is shameful and an outrage! Though Nigeria (a Third World nation) should not be compared with the developed world. Teachers (and traditional students) in the US, for instance, are encouraged to acquire computer skills with moral and financial supports (they are provided with loans to enable those in need to upgrade their skills). Support is a major part in making any changes in life. It is therefore essential to provide our teachers with moral and financial support in their quest to acquire computer skills. As Wang has rightly noted, "In order to get teachers hooked, training needs to stimulate teachers' curiosity and engage them cognitively". Teachers would normally be motivated once they perceived the computers as useful teaching tool. Nigeria cannot make any progress if it continues to pretend that everything is well in the society. Therefore, there is an urgent need for Nigeria to modernize her educational institutions by computerizing the schools, and connect them to the Internet.

Joseph, Olarinye, and Emmanuel outlined the constraints to the use of ICT in the Universal Basic Education to include the following [14]: a. Economy: ICT facilities are expensive, in a poor economy, it might not be possible to procure the components of the ICT.

b. Lack of sufficient computer experts may hinder the effective impartation of computer literacy among teachers and students.

c. Lack of constant electricity power would not permit the teachers to constantly hold computer lesson.

Information and communication technology are derived from combining two technologies, information technology and communication technology. Information technology (IT) refers to a powerful collection of elements, which include computer hardware, computer software, telecommunication network workstations and robotics Joseph, Olarinye, and Emmanuel [14]. Communication technology is the ability to tap any data or information in any outside data bank called a network, a collection of hardware and software that enables a group of computers to communicate with each and allows network users to share resources in computer network.

Information and communication Technology (ICT) may be viewed in different ways. Rodriguez and Rodriguez, and Wilson (2000) defined ICT as a set of activities which facilitate by electronic means the processing, transmission and display of information. ESCAP (2000) in its own definition defined ICT as techniques people use to share, distribute, gather information and to communicate through computers and computer networks. Marcelle described ICT as a complex varied set of goods, applications and services used for producing, distributing, processing, transforming information (including) telecoms, TV and radio broadcasting, hardware and software, computer services and electronic media [7]. Communication technology is the ability to tap any data or information in any outside data bank called a network, a collection of hardware and software that enables a group of computers to communicate with each and allows network users to share resources in computer network.

On the other hand, Landu refers to information and communication technology as the creation, processing, storage retrieval and transmission of data information [9]. Looking at ICT from educational point of view, Joseph, Olarinye, and Emmanuel described ICT as a combination of computer and telecommunication technologies to improve quality of education through processing, editing, storage, retrieval and dissemination of information with sound, motion pictures and diagrams [14].

Computer is an electro-mechanical device that is 
capable of accepting data through an input device, processing these data in its processor and bring out the result of the processed data via an out-put device. It is capable of storing information and obeying instruction in a programme a high speed. It carries out operations such as arithmetic, logic, manipulative on various categories of data such as business or scientific data and subsequently, comes out with results. According to Ayeni computer (assisted) Instruction/Learning training is the use of computer as integral part of an instructional system with the learners generally engaging in real-time interaction with the computer via a terminal [10]. From the above definitions, ICT which includes computer is a communicative tool that facilitates learning in and outside educational settings.

\section{Purpose of the study}

Considering how important and relevance ICT is in educational programme. In Nigeria literature review has shown that teachers' are not able to apply ICT in teaching school subjects in Nigerian secondary schools. Majority of secondary school teachers do not use computers while teaching their lessons. The few that are computer literate are not able to make use of the skill due to many factors that are aforementioned. Though, of recent the authorities concerned in educational matters have stressed the need for the teachers to be computer literate. In some cases, some state government have reported that they have bought and distributed computers to teachers. This study was embarked upon to determine the extent of computer literacy among undergraduate teachers in the Federal Capital Territory (FCT), Abuja Nigeria. Specifically the study to determine the following:

1. Extent of computer literacy among the undergraduate student-teachers.

2. Provision and availability of computers in the secondary schools where they teach.

3. Whether there is any significant difference between urban and rural undergraduate studentteachers perception of the availability of computer in their various school.

\section{Research Questions}

1. To what extent are the undergraduate studentteachers computer literate?

2. To what extent are provision and availability of computers in secondary schools you teach?

\section{Hypothesis}

There is no significant difference between urban and rural undergraduate student-teachers perception of the availability of computer in their various school.

\section{Research methods}

The sample for this study comprised SeventyFour undergraduate student teachers selected through stratified random technique drawn from all the sandwich programme (Teacher Long Vacation Training) who are embarking on differences degree programmes in the University of Abuja in Nigeria, formed the sample for the study. The instrument for the study was questionnaires containing the extent of computer literacy and availability, drawn from literature reviews formed the instrument for this study.

For reliability of the instrument, a pre-test was conducted using the undergraduate student in the faculty of education, at the department of arts and social science education, the reliability was found to 0.72. The validity of the questionnaire was determined by curriculum expert in the faculty of education, University of Abuja, Nigeria. Responses to items in the questionnaire which were on a four point -4 point Likert scale format were assigned numeric values. Ranging from +1 to +4 for the purpose of data analysis, for instance strongly agree was cited 4 points, agree +3 , disagree +2 , strongly disagree +1 . A mean score of 2.5 and above was regarded as positive, which means an agreement while mean score of below 2.5 was regarded as negative meaning disagreement. The data was analysed using percentages and T-test.

\subsection{Data presentation and Analyse}

Table 1 was used to answer research questions one to three as stated in this study.

\subsubsection{Research question one}

1. To what extent are the undergraduate studentteachers computer literacy? 
Table 1. The extent of computer literacy of teachers

\begin{tabular}{|c|c|c|c|c|c|c|}
\hline $\mathrm{S} / \mathrm{N}$ & Literacy and Availability & Agree & $\%$ & Disagree & $\%$ & Total \\
\hline & You are not computer literate & 50 & 68 & 24 & 32 & 74 \\
\hline 2 & $\begin{array}{l}\text { You can use Microsoft Word to type questions and other } \\
\text { document }\end{array}$ & 38 & 51 & 56 & 49 & 74 \\
\hline 3 & You can use Microsoft Excel for basic mathematics & 12 & 16 & 62 & 84 & 74 \\
\hline 4 & You can use PowerPoint In Presenting lecture slides & 6 & 8 & 68 & 92 & 74 \\
\hline 5 & You can browse the Internet to get materials for lectures & 13 & 18 & 61 & 82 & 74 \\
\hline 6 & You can check your e-mails on the internet & 21 & 28 & 53 & 72 & 74 \\
\hline 7 & You can use a search engine such as Google, Bing, ask, ECT. & 20 & 27 & 54 & 73 & 74 \\
\hline 8 & You can set up a database using MS Access & 12 & 16 & 62 & 84 & 74 \\
\hline 9 & You can use a scanner to scan images & 11 & 15 & 63 & 85 & 74 \\
\hline 10 & You can operate a printer that is connected to the computer & 36 & 49 & 38 & 51 & 74 \\
\hline
\end{tabular}

The table above shows the extent of undergraduate student teachers literacy level. The analysis shows that 50 students representing $68 \%$ said that they were not computer literate, while 24 students representing $32 \%$ students said they were. 38 representing $51 \%$ said they can use Microsoft Word to type questions and other document, while 56 students representing $49 \%$ students said they cannot. 12 students representing $16 \%$ students said they can use Microsoft Excel for basic mathematics, while 62 students representing $84 \%$ students said they cannot. 6 students representing $8 \%$ students said they can use PowerPoint in Presenting lecture slides while 68 students representing 92\% students said they cannot. 13 students representing $28 \%$ students said they can browse the Internet to get materials for lectures while 61 students representing $82 \%$ students said they cannot. 21 students representing $28 \%$ students said they can check their e-mails on the internet, while 53students representing $72 \%$ students said they cannot. 20 students representing $27 \%$ students said they can use a search engine such as Google, Bing, ask, ECT. While 54students representing $73 \%$ students said they cannot. 12 students representing $16 \%$ students said they can set up a database using MS Access, while
62 students representing $84 \%$ students said they cannot. 11 students representing $15 \%$ students said they can use a scanner to scan images, while 63 students representing $85 \%$ students said they cannot. 36 students representing $49 \%$ students said they can use operate a printer that is connected to the computer, while 38 students representing $51 \%$ students said they cannot.

\subsubsection{Research question two}

1. To what extent are provision and availability of computers in secondary schools you teach? 
Table 2. Provision and availability of computers in secondary schools

\begin{tabular}{|l|l|l|l|l|l|l|l|}
\hline Nos & PROBLEMS & S A & A & D & $\begin{array}{l}\text { S } \\
\text { DEA }\end{array}$ & TOTAL \\
\hline 1 & Computer materials are supplied to our school & 6 & 20 & 15 & 33 & 1.97 & 74 \\
\hline 2 & Computer is taught in my school & & & & & \\
\hline 3 & At least 10\% of teachers have computer in my schools & 11 & 20 & 19 & 24 & 1.57 & 74 \\
\hline 4 & At least 20\% of teachers have computer in my schools & 9 & 13 & 25 & 27 & 2.43 & 74 \\
\hline 5 & At least 50\% of teachers have computer in my schools & 12 & 9 & 19 & 34 & 1.97 & 74 \\
\hline 6 & You are willing to attend computer school if sent & 38 & 36 & & - & 3.51 & 74 \\
\hline 7 & There are least two to three computer teachers in our school & 19 & 25 & 13 & 17 & 2.62 & 74 \\
\hline 8 & There are least four to five computer teachers in our school & 10 & 18 & 21 & 25 & 2.18 & 74 \\
\hline 9 & There is a computer studio in my school & & & & & & \\
\hline 10 & Light is always available to operate the computers & 14 & 10 & 15 & 35 & 2.04 & 74 \\
\hline
\end{tabular}

Table 2 shows provision and availability of computers in secondary schools under study. The analysed data reveals that with a mean of 1.97 suggests that majority of the undergraduate studentteachers said that computer materials are not supplied to their schools. The mean of 2.23 suggests that majority of the undergraduate student-teachers claim that computer is not taught in my school. The mean of 1.57 on if "at least $10 \%$ of teachers have computer in my schools suggests that majority of the undergraduate student-teachers disagreed. The mean of 2.43 on if "at least $20 \%$ of teachers have computer in my schools suggests that majority of the undergraduate student-teachers disagreed. The mean of 1.97 on if "at least $50 \%$ of teachers have computer in my schools" suggests that majority of the undergraduate student-teachers disagreed. The mean of 3,51 suggests that majority of the undergraduate student-teachers are willing to attend computer training if sponsored. The mean of 2.62 suggests that majority of the undergraduate student-teachers agreed that there are least two to three computer teachers in their school. The mean of 2.18 suggests that majority of the undergraduate student-teachers disagreed that there are least four to five computer teachers in our school. The mean of 1.91 suggests that majority of the undergraduate student-teachers disagreed that they have a computer studio in their schools. The mean of 2.04 suggests that majority of the undergraduate student-teachers disagreed that light is always available to operate the computers in their schools.

\section{Hypothesis}

There is no significant difference between urban and rural undergraduate student-teachers perception of the availability of computer in their various school.

Key:

Strongly Agree $=$ SA, Agree = A,

Disagree $=\mathrm{D}$, Strongly Disagree $=\mathrm{SD}$

Total $=\mathrm{T}$, Total Male $=\mathrm{TM}$, Total female $=\mathrm{TF}$, Grand Total $=$ GT, Mean $=\mathrm{M}$ 
Table 3. Difference in urban and rural undergraduate student-teachers mean scores perception on computer literacy and computer availability.

\begin{tabular}{|c|c|c|c|c|c|c|c|c|c|c|c|c|c|c|}
\hline \multirow[b]{2}{*}{$S / N$} & \multirow[b]{2}{*}{ LITERACY and AVAILABILITY } & \multicolumn{6}{|c|}{ URBAN TEACHERS $\quad(\mathrm{N}=40)$} & \multicolumn{7}{|c|}{ RURAL TEACHER (N = 34) } \\
\hline & & $\mathrm{SA}$ & A & $\mathrm{D}$ & SD & $\mathrm{M}$ & UT & SA & $\bar{A}$ & $\mathrm{D}$ & SD & Mean & RT & GT \\
\hline 1 & You are not computer literate & 14 & 14 & 6 & 10 & 3.00 & 40 & 12 & 9 & 7 & 6 & 2.79 & 34 & 74 \\
\hline 2 & You do not have a computer & 12 & 12 & 9 & 7 & 3.73 & 40 & 12 & 10 & 4 & 8 & 2.76 & 34 & 74 \\
\hline 3 & $\begin{array}{l}\text { You bought the computer with your } \\
\text { money }\end{array}$ & 10 & 12 & 10 & 8 & 2.60 & 40 & 7 & 11 & 7 & 9 & 2.88 & 34 & 74 \\
\hline 4 & $\begin{array}{l}\text { Government supplied you with } \\
\text { computer }\end{array}$ & 8 & 6 & 15 & 11 & 2.43 & 40 & 5 & 7 & 18 & 4 & 2.38 & 34 & 74 \\
\hline 5 & $\begin{array}{l}\text { At least } 10 \% \text { of teachers have } \\
\text { computer in my schools }\end{array}$ & 9 & 8 & 14 & 9 & 2.63 & 40 & 7 & 10 & 10 & 7 & 2.5 & 34 & 74 \\
\hline 6 & $\begin{array}{l}\text { At least } 20 \% \text { of teachers have } \\
\text { computer in my schools }\end{array}$ & 5 & 6 & 19 & 10 & 2.18 & 40 & 5 & 4 & 10 & 15 & 1.97 & 34 & 74 \\
\hline 7 & $\begin{array}{l}\text { At least } 50 \% \text { of teachers have } \\
\text { computer in my schools }\end{array}$ & 8 & 4 & 16 & 12 & 2.45 & 40 & 3 & 5 & 12 & 14 & 1.91 & 34 & 74 \\
\hline 8 & $\begin{array}{l}\text { You are willing to attend computer } \\
\text { school if sponsored }\end{array}$ & 30 & 6 & 3 & 1 & 3.63 & 40 & 24 & 6 & 3 & 3 & 3.62 & 34 & 74 \\
\hline & & & & & & 2.81 & & & & & & 2.60 & & \\
\hline
\end{tabular}

Table 4. Two Sample T-test for Difference between the Male Teachers and Female Teachers' Perception as Regards Computer Literacy and Computer Availability in their Schools

\begin{tabular}{|c|c|c|c|c|c|c|c|}
\hline Location of school & Mean & V & N. & df & t stat & t-crit & Remark \\
\hline URBAN & 2.831 & 0.328 & 40 & & & & \\
\hline RURAL & 2.601 & 0.301 & 34 & & 0.8195 & 1.181 & INS \\
\hline
\end{tabular}

Table 4 shows urban and rural undergraduate studentteachers perception as regards provision and availability of computers in their schools. The result shows that the calculated t stat value of 0.8195 is less than the $t$ crit. value of 1.781 at the degree of freedom of 0.05 level of significances. This result suggests that the null hypothesis which stated that there was no significant difference between the undergraduate urban teacher students and undergraduate rural teacher students' perception as regards provision and availability of computer was upheld. Therefore, the views of male and female undergraduate studentteachers to computer literacy and computer availability in their schools are the same.

\section{Discussion}

The study has shown that sixty-eight per cent $(68 \%)$ respondents are not computer literate. This is in agreement with Wang who stated that there are an alarming number of people in Nigeria (university professors and high school teachers included) who do not know how to simply turn on a computer [18]. Majority of secondary school teachers do not use computers while teaching their lessons. In addition, Onyechu observed that teachers' inability to apply ICT in teaching school subjects in our secondary schools is one of the problems militating against effective implementation of secondary education curriculum [11]. Fifty-one per cent $(51 \%)$ of the 
students teachers reported that they bought computers with their money. This goes to confirm Onyeachu, who observed many institutions in these countries cannot afford to buy or have access to computers and even where computers are available or can be purchased, there is lack of the human and material resources to use ICT [11]. Furthermore, the poor socio-economic condition in most developing countries of the world, including Nigeria, has compelled the governments and institutions to show little concern for the application of ICT in education.

The analysis of the data reveal that the respondents are made up of both old and new teachers are willing to go for computer training, if given the opportunity. This finding is contrary to Wang (2000) views that teachers of old (those who have been in the field long before the advent of the computers in the classroom) are intimidated by the computers. A mean of 3.62 and 3.63 recorded for both urban and rural undergraduate student- teachers on the question if they are willing to attend computer school if sponsored, shows how eager they are to become computer literates. Also, both urban and rural undergraduate student- teachers had the same views in terms of provision and availability of computers in their schools.

\section{Recommendations}

1. Teachers (and traditional students) in the US, for instance, are encouraged to acquire computer skills with moral and financial supports (they are provided with loans to enable those in need to upgrade their skills). It therefore recommends that opportunities to acquire computer skills should be made available for our teachers, through government partnership with banks.

2. The study has revealed that only a few teachers have computer, it has therefore, become necessary that both state and federal the government should ensure that they supply teachers in secondary schools. This is because not all teachers can asses loan from the bank due to the stringent conditions attached to obtaining loan.

3. Those teachers who are already in the field (but lack the needed skills) should be encouraged to acquire the necessary skill through staff development (or in-service training). The staff development exercise should be a continuing process so as to update their skills.

4. Our educational system is besieged with politics; this is because people who plan for the educational programme know little about education. It is therefore necessary that the government should hand over educational matters in the hand of experts.

\section{Conclusion}

The study was embarked upon to determine the extent of computer literacy among undergraduate student-teachers in the University of Abuja in Nigeria. The reviewed literatures revealed that Nigeria is still very backward in tends of computer literacy as a number of people in Nigeria (university professors and high school teachers included) who do not know how to simply turn on a computer. Many institutions in these countries cannot afford to buy or have access to computers and even where computers are available or can be purchased; there is lack of the human and material resources to use ICT. The study concluded that it has become necessary that both state and federal the government should ensure that they supply teachers in secondary schools. Those teachers who are already in the field should be encouraged to acquire the necessary skill through staff development (or in-service training). The staff development exercise should be a continuing process so as to update their skills. Finally, government should hand over educational matters in the hand of experts.

\section{References}

[1] Adomi, E. E. and Kpangban, E., (2010). Application of ICTs in Nigerian Secondary schools. Library Philosophy and Practice 2010. ISSN 1522 - 0222, http://digitalcommons.unl.edu/libphilprac/345 (Access date: 13 January 2012)

[2] Anon, (2009). "The universal basic education program, the essence of technology, and well trained educators": Educating the educators in Nigeria. International Journal of Research Development, 2009. Pp. 661-667.

[3] Cheng, Y., (2003). The Effects of Web Based Instruction on Chinese EFL Students, Learning Outcomes. Dissertation Abstracts International 62 (2)

[4] Economist Intelligence Unit in (2008)

[5] E N. Ariza, et al., "Uniting teachers to embrace 21st century technology: A critical mass in a cohort of colleagues." The Journal, 2000, 27(10), 22-30.

[6] ESCAP, 'Are ICT Policies Addressing Gender Equality'? http//www.unescaporg/wid/04/ wideresources/11 wideactivities/01 cctegm/backgoundpaper. (3 April 2000).

[7] Marcelle, G., Gender Justice and ICTs. http://www.un.org/womenwatch_daw/csw/marcello.htm. (Access date: 3 Feburary2000).

[8] F. Rodriguez, and E. Wilson, (2000). Are Poor 
Countries Losing the Information Revolution? mfoDev Working Paper. Washington D.C. World Bank.

[9] I. T. Landu "Information and communication technology in Nigeria" Journal of Science and Educational Research in Collaboration with Association of science Education of Nigeria.1 (1), (2003) 49.

[10] J. Ayeni, "Information communication teaching (ICT) as a basis for quality assurance in primary education level" Journal of Curriculum Studies, (2008), 15 (3), 110 -11.

[11] J. A. E. Onyeachu, "Integration of ICT(s) in teaching and distance learning in Nigeria". Technological. Writers Association of Nigeria (TEWAN), Abia state University, Uturu. (2007).

[12] J. O. Ezema, "E-Learning "A new model for teaching in the $21 \mathrm{st}$ century" Department of Educational Foundations, Enugu State University of Science and Technology, (Esut) Enugu, Nigeria. E-Learning: A New Model for Teaching in the 21sCentury (2002), 599.

[13] M. Obike, and S. T. Afangideh, "Utilization of educational resources and educational development in Nigeria: A critique". International Journal of Research Development (2009), 583-588.

[14] N. G., Joseph, R. D. Olarinye, and J.E., Emmanuel, in G. A Ike, and C. Ihebereme, "Role and management of information and communication technology in primary education curriculum to achieve quality assurance" Journal of Curriculum Studies, (2008), 15 (4), 66 - 69.

[15] N. Hedge, and L. Hayward, " Redefining roles. University e-learning contributing to Life-long learning in a networked world". E-Learning, Journal of the Nigerian cartography Association. 771, (2004), 128 - 145.

[16] S. E. Aduwa-Ogiegbaen, \& E. O. S. Iyamu, "Using Information and Communication Technology in Secondary Schools in Nigeria: Problems and Prospects". Educational Technology \& Society, 8 (1), (2005), 104-112.

[17] R. G. Chattel, "New Technology, New Literacy": Creating a Bridge for English language Learners. The New England Reading Association Journal 38(3) (2002), 45 49.

[18] Y. M. Wang, "Training of teachers using computers: A process of familiarization, utilization, and integration"; The Journal; 27 (10), (2000), 66-74. 